\title{
Performance Evaluation of an Adjustable and Collapsible Natural Convection Solar Food Dryer
}

\author{
${ }^{1}$ Yusuf Abdullahi, ${ }^{2}$ Musa Momoh, ${ }^{3}$ Mahmoud Mhammad Garba and ${ }^{4}$ Muazu \\ Musa \\ ${ }^{1 \& 2}$ Department of Physics, Usmanu Danfodiyo University Sokoto, Nigeria. \\ ${ }^{3 \& 4}$ Sokoto Energy Research Centre Sokoto, Nigeria
}

\begin{abstract}
The performance evaluation of an adjustable and collapsible natural convection solar food dryer, capable of taking 14,688 pieces equivalent to $16.52 \mathrm{~kg}$ of fresh groundnut with maximum moisture content of $35 \%$, at maximum capacity of $3.39 \mathrm{~m}^{2}$, and 3,672 pieces equivalent to $4.06 \mathrm{~kg}$ of groundnut at minimum capacity of $0.8475 \mathrm{~m}^{2}$, was carried out. The solar food dryer with air vents gap diameter of $10 \mathrm{~cm}$ was tested at Sokoto Energy Research Centre from $29^{\text {th }}$ September 2012 to $1^{\text {st }}$ October 2012. It was used to dry $6 \mathrm{~kg}$ of groundnut per day for three consecutive days. After drying for about 8 hours each day, it was found that the mass of the groundnut reduced to $4.5 \mathrm{~kg}$ in the first day, $4.0 \mathrm{~kg}$ in the second day and $3.5 \mathrm{~kg}$ in the third day. At the end of the study, the collector's efficiency was $28.3 \%$, dryer's efficiency was $23.0 \%$ and the system efficiency was $81.3 \%$, while the drying rate of groundnut was $0.25 \mathrm{~kg} / \mathrm{hr}$
\end{abstract}

\section{Introduction}

The food scientist have found that by reducing the moisture content of food to between $10 \%$ and $20 \%$, bacteria, yeast, moulds and enzymes are all prevented from spoiling it since micro organisms are effectively killed when the internal temperature of food reaches $14{ }^{\circ} \mathrm{f}$ (Harringshaw,1997). The flavor and most of the food nutritional value of dried food is preserved and concentrated (Scalin,1997). Moreover dried food does not require any special storage equipment and are easy to transport (Scalin1997). In ancient time of alchemy, drying was by natural "sun drying" and today in most rural communities of developing countries it is still being practiced. The diverse crops are spread on the ground and turned regularly until sufficiently dried so that they can be stored safely.

Direct sun drying is associated with numerous shortcomings, as products are affected by ultraviolet radiation, dust, rain showers, morning dews, animal and human interference, to mention but a few. In addition, open sun drying is slow, has no quality control and has a risk of contamination, creating a potential health hazard. The product's quality is seriously degraded, sometimes to the extent that they are inedible (Whitefeild,2000;Diamante \& Munro 2004). These caused huge post harvest losses and significantly contributed to non availability of food in some developing countries. Estimation of these losses are generally cited to be order of $40 \%$, but they can be nearly $80 \%$ (Bassey,1989; Togrul and Pehlivan,2004). Artificial mechanical drying method such as electric dryers, wood fueled dryers and oil burn dryers were therefore introduced mostly in developing countries (Nejat.1989). However increase in the cost of electricity and fossil fuel has made these dryers very non-attractive. Although the spreading of the crop on the ground or on a platform and drying it directly by sun drying is cheap and successfully employed for many products throughout the world, where solar radiation and other climatic conditions are favorable, because of the disadvantages of open-air sun drying process, high cost of mechanical drying mentioned above and a better understanding of the method of utilizing solar energy to advantage, have given rise to a scientific method called solar drying (Aklilu.2004). In solar drying, solar dryers are specialized device that controls the drying process and protect agricultural produce from damage by insect, pest, dust and rain, and in comparism to the natural sun drying, solar dryers generates higher temperatures lower relative humidity, lower produce moisture content, and reduce spoilage during the drying process, in addition, it takes up less space, take less time and relatively inexpensive compared to artificial mechanical drying method (Geda- Gujurat Energy Development Agency, 2003, www.geda.com). Studies showed that food item dried in a solar dryer were superior to those which are sun dried when evaluated in terms of taste, color and mould contents (Nandi, 2009). According to Oguntola. et,al.(2010), solar dried food are quality products that can be stored for extended periods, easily transported at less cost while still providing excellent nutritive values. Thus solar drying is a better alternative solution to all the drawbacks of natural sun drying and artificial mechanical drying.

Solar drying has been considered a healthy and efficient means of food preservation most and importantly, solar dried items are healthy and delicious, outdoor sun drying is best carried out in hot, dry and breezy days. Under current drying techniques, solar drying offers a limited but feasible economic alternative to farmers, households and others (Hallak et al., 1996). Different types of solar dryer are becoming increasingly 
popular as an alternative drying process for healthy dried food products, both for family consumption, and in food processing as an enterprise to support livelihood through selling value added products (Mahmoud,2009). According to Roger \& Gregoire (2010), a minimum temperature of $30^{\circ} \mathrm{C}$ is needed with a relative humidity preferably below 60 percent, and optimum temperature of $60^{\circ} \mathrm{C}$ for drying most food products is reported adequate for removing moisture from the food crops, so that yeasts, bacteria and moulds cannot grow. If higher temperatures are used, the crop will cook instead of drying (Mahmoud,2009)

\section{Calculations / Theory}

(i) Angle of tilt ( $\beta$ ) of solar collector

According to Sukhatme (1996), angle of tilt ( $\beta$ ) of solar collectors is

$\beta=10+$ lat $\phi$

Where lat $\phi=$ latitude of the place that the drier was designed, which is Sokoto. For the purpose of this design, $\beta=$ lat $\phi . \phi$ which is the latitude of Sokoto is $13.3^{\circ}$ (Sokoto Ministry of Land and Survey Sokoto) since there was no angle of tilt. The dryer could function satisfactorily without angle of tilt.

(ii)There are three major factors affecting food drying: temperature, humidity and air flow. They are interactive. Increasing the vent area by opening vent covers will decrease the temperature and increase the air flow, without having a great effect on the relative humidity of the inlet air. In general more air flow is desired in the early stages of drying to remove free water or water around the cells and on the surface. Reducing the vent area by partially closing the vent covers will increase the temperature and decrease the relative humidity of the inlet air and the air flow (Wave Power Plant Inc. 2006). Oguntola et,al (2010) reported that volumetric flow rate of air $\mathrm{V}_{\mathrm{a}}$ can be expressed as $V_{a}=v(m / s) \times h(m) \times w(m)$, Where $\mathrm{v}$ is the average air wind speed in $(\mathrm{m} / \mathrm{s})$, h is the height of the air gap or vent in $(\mathrm{m}), \mathrm{w}$ is the width of the collection which, implies the air gap or vent in $(\mathrm{m})$. This implies that $V_{a}=v(m / s) \times A\left(m^{2}\right)$, A is the area of air gap or vent in $\left(\mathrm{m}^{2}\right)$. For the purpose of this design, the air inlet and outlet gaps or vents are circular in shape, therefore, the formula used to calculate the volumetric flow rate of air is average wind speed $(\mathrm{m} / \mathrm{s})$ multiply by the area of the air gaps or vents which are circular in shape. It is expressed as

$V_{a}=A \times v \times n$

Where $V_{a}=$ Volumetric flow rate of air $\left(\mathrm{m}^{3} / \mathrm{s}\right)$

$A=$ Area of air gap or vent $\left(\mathrm{m}^{2}\right)$

$v=$ average wind speed $(\mathrm{m} / \mathrm{s})$

$n=$ number of air vents

But $A=\pi \mathrm{r}^{2}, r=$ radius of air or vent

so that, we obtain

$V_{a}=\pi r^{2} \times v \times n=\pi v r^{2} n$

(iii) Mass flow rate of air is expressed (Oguntola, 2010) as

$m_{a}=\rho_{a} V_{a}$

Where $m_{a}=$ mass flow rate of air, $\rho_{a}=$ density of air $\left(\mathrm{kg} / \mathrm{m}^{3}\right)$ and $V_{a}=$ volumetric flow rate of air $\left(\mathrm{m}^{3} / \mathrm{s}\right)$

(iv) Solar insolation is given by Olaloye(2008) as

$I_{c}=\mathrm{H} \times \mathrm{R}$

Where $I_{c}=$ solar insolation $\left(\mathrm{W} / \mathrm{m}^{2}\right)$

$\mathrm{H}=$ average daily solar radiation on horizontal surface Olaloye (2008)

$\mathrm{R}=$ average effective ratio of solar energy on tilt surface to that on the horizontal surface $=1.0035$.

For the purpose of this design, $I_{c}=\mathrm{H}$, because the solar collector was not tilted to any surface hence no any effective energy ratio $R$.

(v) Energy Balance on the Absorber.

The total heat energy gained by the collector's absorber is equal to the heat lost by heat absorber of the collector (Bukola et,al 2008)

$I_{c} A_{c}=Q_{u}+Q_{\text {cond }}+Q_{\text {convec }}+Q_{R}+Q_{p}$

$I_{c}=$ rate of total radiation incident on the absorber's surface $\left(\mathrm{W} / \mathrm{m}^{2}\right)$ 
$\mathrm{A}_{\mathrm{c}}=$ collector's area $\left(\mathrm{m}^{2}\right)$

$\mathrm{Q}_{\mathrm{u}}=$ rate of useful energy collected by the air $(\mathrm{W})$

$\mathrm{Q}_{\text {cond }}=$ rate of conduction losses by the absorber $(\mathrm{W})$

$\mathrm{Q}_{\text {convec }}=$ rate of convective losses from the absorber $(\mathrm{W})$

$\mathrm{Q}_{\mathrm{R}}=$ rate of long wave re - radiation from absorber $(\mathrm{W})$

$\mathrm{Q}_{\mathrm{P}}=$ rate of reflection losses from the absorber $(\mathrm{W})$

Putting $Q_{l}=Q_{\text {cond }}+Q_{\text {convec }}+Q_{R}$

where $Q_{l}$ is the total heat loses( the three heat losses)

If $\tau$ is the transmittance of the top glazing and It is the total solar radiation incident on the top surface, therefore,

$I_{c} A_{c}=\tau I_{c} t A_{c}$

The reflected energy from absorber is given by expression

$Q_{p}=\rho \tau_{c} t A_{c}$

$\rho=$ reflection co- efficient of absorber.

Substituting eqn (8), (9) and (10) into (7), yields

$\tau \mathrm{I}_{c} t A_{c}=Q_{u}+Q_{l}+\rho \tau \mathrm{I}_{c} t A_{c}$

$Q_{u}=\tau I_{c} A_{c}(1-\rho)-Q_{l}$

For an absorber, $(1-\rho)=\alpha$ and hence,

$Q_{u}=(\alpha \tau) I_{c} t A_{c}-Q_{l}$

$Q_{l}$ composed of different convection and radiation parts. It is presented in the following form (Bansel et,al. 1990)

$Q_{l}=U_{l} A_{c}\left(T_{c}-T_{a}\right)$

$U_{l}=$ overall heat transfer co - efficient of the absorber $\left(\mathrm{W} / \mathrm{m}^{2} \mathrm{~K}^{-1}\right)$

$T_{c}=$ temperature of collector's absorber $(\mathrm{K})$

$T_{a}=$ ambient air temperature $(\mathrm{K})$.

$Q_{u}=(\alpha \tau) I_{c} t A_{c}-U_{l} A_{c}\left(T_{c}-T_{a}\right)$

If the heated air leaving the collector is at the collector's temperature, the heat gained by the air Qg is

$Q_{g}=m_{a} c_{p a}\left(T_{c}-T_{a}\right)$

$m_{a}=$ mass of air leaving the dryer per unit time $(\mathrm{kg} / \mathrm{s}) \equiv$ mass flow rate of air $\equiv \dot{m}$

$c_{p a}=$ specific heat capacity of air at constant pressure $\left(\mathrm{jkg}^{-1} \mathrm{k}^{-}{ }^{1}\right)$

The collector's heat removal factor, $F_{R}$, is the quantity that relates the actual useful energy gain of a collector in eqn (13) to the useful energy gained by air in eqn (14) expressed by (Bukola and Ayoola,2008) as

$\mathrm{F}_{\mathrm{R}}=\frac{m_{a} c_{p a}\left(T_{c}-T_{a)}\right.}{A_{c}\left[\tau \alpha I_{c} t-U_{l}\left(T_{c-} T_{a}\right)\right]}$

Equation (14) can be re- written in terms of $F_{R}$

$Q_{g}=A_{c} F_{R}\left[(\alpha \tau) I_{c} t-U_{l} A_{c}\left(T_{c}-T_{a}\right)\right]$

The thermal efficiency of the collector is defined as the ratio of heat output to the heat input or ratio of energy output to energy input, which is the same as the ratio of the energy addition to the air as it passes through the collector to the energy incident on the collector.

$\eta_{c}=\frac{Q g}{I_{c} A_{c}}$

(vi) The total energy required for drying a given quantity of food item can be estimated using basic energy balance equation for the evaporation of water (Youcef et,al. 2001, and Bolaji 2005) as in equation 18, where the oil and fat evaporated from groundnut is negligible at that temperature change.

$m_{w} L_{v}=m_{a} c_{p a}\left(T_{1}-T_{2}\right)$ 
$\mathrm{m}_{\mathrm{w}}=$ mass of water vapour evaporated from the food item $(\mathrm{kg})$

$\mathrm{L}_{\mathrm{v}}=$ latent heat of vaporization of water $(\mathrm{kj} / \mathrm{kg})$

$\mathrm{m}_{\mathrm{a}}=$ mass of drying air $(\mathrm{kg})$

$\mathrm{T}_{1}$ and $\mathrm{T}_{2}=$ the initial and final temperatures of drying air respectively $(\mathrm{K})$

$\mathrm{C}_{\mathrm{p}}=$ specific heat capacity of air at constant pressure $\left(\mathrm{kjkg}^{-1} \mathrm{k}^{-1}\right.$

(vii) The dryer's efficiency (nd) is expressed as follows

$n_{d}=\frac{M L_{v}}{I_{c} A_{c} t}$

$\eta_{d}=$ dryer's efficiency $(\%)$

$\mathrm{M}=$ Mass of moisture evaporated $(\mathrm{kg})$

$\mathrm{L}_{\mathrm{v}}=$ Latent heat of vaporization of water $(\mathrm{kj} / \mathrm{kg})$

$\mathrm{I}_{\mathrm{c}}=$ Solar insolation $\left(\mathrm{W} / \mathrm{m}^{2}\right)$

$\mathrm{A}_{\mathrm{c}}=$ Area of solar collector $\left(\mathrm{m}^{2}\right)$

$\mathrm{t}=$ Time of drying (hrs)

(viii) The collector's efficiency (nc) is expressed (Ezekoye and Enibe2006) as follows

$n c=\frac{\rho V_{a} C_{p} \Delta T}{I_{c} A_{c}}$

$\eta \mathrm{c}=$ Collector's efficiency $(\%)$

$\mathrm{Cp}=$ Specific heat capacity of air $(\mathrm{kj} / \mathrm{kg} \mathrm{k})$

$\Delta \mathrm{T}=\left(\mathrm{T}_{\mathrm{c}}-\mathrm{T}_{\mathrm{a}}\right)=$ Temperature elevation $(\mathrm{K})$

$\mathrm{A}_{\mathrm{c}}=$ Area of solar collector $\left(\mathrm{m}^{2}\right)$

$\mathrm{I}_{\mathrm{c}}=$ solar insolation $\left(\mathrm{W} / \mathrm{m}^{2}\right)$

$\rho=$ Density of air $\left(\mathrm{kg} / \mathrm{m}^{3}\right)$

$\mathrm{V}_{\mathrm{a}}=$ Volumetric flow rate of air $\left(\mathrm{m}^{3} / \mathrm{s}\right)$

(ix) Moisture content on percentage wet basis is expressed (Senger et,al 2009) as follows

$M C_{w b}=\frac{W_{1}-W_{2}}{W_{1}}$

$\mathrm{MC}\left(\mathrm{w}_{\mathrm{b}}\right)=$ Moisture content on percentage wet bases.

$\mathrm{W}_{1}=$ Weight of sample before drying in $\mathrm{kg}$.

$\mathrm{W}_{2}=$ Weight of sample after drying in $\mathrm{kg}$.

(x) Moisture content on percentage dry bases is expressed (Senger et,al 2009) as

$M C_{d b}=\frac{W_{1}-W_{2}}{W_{2}}$

(xi) Drying rate is expressed (Ceankoplis, 1993) as

$R_{c}=\frac{M_{d}\left(Q_{1}-Q_{2}\right)}{A_{s} t}$

Where $\mathrm{R}_{\mathrm{c}}=$ drying rate $(\mathrm{kg} / \mathrm{mol}), \mathrm{M}_{\mathrm{d}}=$ total weight of dried sample, $\mathrm{A}_{\mathrm{s}}=$ surface area of dried solid $\left(\mathrm{m}^{2}\right), \mathrm{t}=$ drying time (hrs), $\mathrm{Q}_{1}=$ initial moisture content $(\% \mathrm{wb})$ and $\mathrm{Q}_{2}=$ final moisture content $(\% \mathrm{wb})$

(xi) Relative humidity is the mass of moisture present in air to the mass of moisture the air is capable of holding at that temperature. 


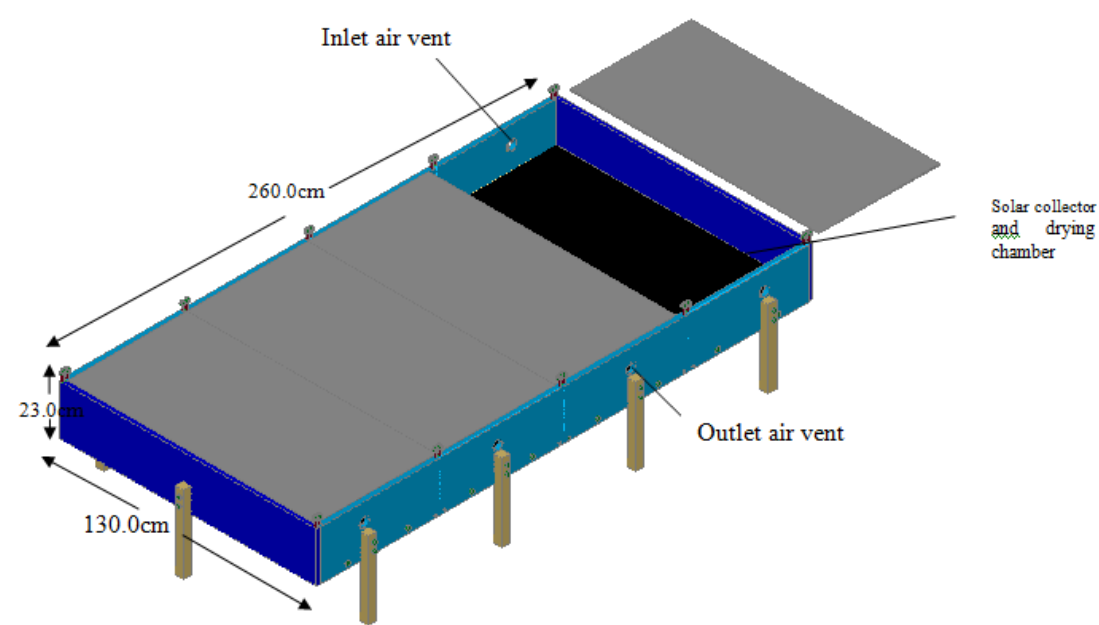

\section{Performance Test}

The Pictorial view of Solar Food Dryer.

The solar food dryer was tested at Sokoto Energy Research Centre, Sokoto - Nigeria, from $29^{\text {th }}$ September 2012 to $1^{\text {st }}$ October 2012. It was used to dry $6 \mathrm{~kg}$ of fresh groundnut each day. Before the test was conducted with material to be dried, the dryer was checked with no load. The sensor E.R.A. type - K digital thermometer was slotted into the dryer and placed about $1 \mathrm{~cm}$ above the solar collector to measure the collector's temperature $\left(\mathrm{T}_{\mathrm{c}}\right)$. The mecury- in- bulb thermometer was vertically slotted into the dryer through an opening created in the glass cover frame with the bulb of the thermometer kept about $20 \mathrm{~cm}$ above the solar collector to measure the drying chamber's temperature $\left(T_{d}\right)$. The Mextech digital multi-thermometer was kept in an open space close to the dryer to measure the ambient temperature $\left(T_{a}\right)$. The sensor of Meteon Irradiance Meter was place on an open space to receive and measure solar insolation $\left(\mathrm{I}_{\mathrm{c}}\right)$. The A.M - 4812 digital Anemometer was placed in the outlet air vent to measure wind speed (v). The dry and wet bulb thermometer (Hygrometer) was placed in an open space close to the dryer to measure dry air temperature $\left(T_{h}\right)$ and wet air temperature $\left(\mathrm{T}_{\mathrm{w}}\right)$ the relative humidity $(\mathrm{RH})$. The glass covers were replaced on the dryer and ready for test. The inlet and outlet air vents were closed until the drying chamber's temperature above $45^{\circ} \mathrm{C}$ was achieved which is required for drying of food. $6 \mathrm{~kg}$ of clean fresh groundnut was weighed and uniformly loaded into the drying chamber, and air vents were open again. The next step was to check to ensure that pynarometer, mextech multi- thermometer, E.R.A. type- K digital thermometer, A.M- 4812 digital anemometer and other measurement instruments were working properly. After a short while, the measurements and recording of variables started from $08.25 \mathrm{hrs}$ to $16.25 \mathrm{hrs}$ at interval of 30 minutes, each day, from $29^{\text {th }}$ September 2012 to $1^{\text {st }}$ October 2012. The mass of groundnut after drying was noted and recorded daily. As the solar drying of groundnut was taking place, $3 \mathrm{~kg}$ of the same fresh groundnut was also spread on the open sun for open- sun drying along side solar drying on the third day to get the rough idea of moisture that will be evaporated from the fresh groundnut after open sun drying for the same period of time as in solar drying during the test. The mass of the groundnut after open-sun drying was also noted and recorded.

\section{Comparism of data collected during the test.}

\section{Result And Discussion}

Table1. The averages of the data collected from $29^{\text {th }}$ September 2012, to $1^{\text {st }}$ October 2012

\begin{tabular}{|l|l|l|l|}
\cline { 2 - 4 } \multicolumn{1}{c|}{} & $29 / 9 / 2012$ & $30 / 9 / 2012$ & $1 / 10 / 2012$ \\
\hline $\mathrm{T}_{\mathrm{a}}\left({ }^{\circ} \mathrm{C}\right)$ & 33.39 & 32.50 & 33.14 \\
\hline $\mathrm{T}_{\mathrm{c}}\left({ }^{\circ} \mathrm{C}\right)$ & 70.39 & 67.29 & 61.47 \\
\hline $\mathrm{I}_{\mathrm{c}}\left(\mathrm{W} / \mathrm{m}^{2}\right)$ & 808.36 & 772.35 & 645.65 \\
\hline $\mathrm{v}(\mathrm{m} / \mathrm{s})$ & 0.51 & 0.51 & 0.55 \\
\hline $\mathrm{T}_{\mathrm{h}}\left({ }^{\circ} \mathrm{C}\right)$ & 41.50 & 41.85 & 40.44 \\
\hline $\mathrm{T}_{\mathrm{w}}\left({ }^{\circ} \mathrm{C}\right)$ & 28.63 & 28.71 & 29.18 \\
\hline $\mathrm{T}_{\mathrm{d}}\left({ }^{\circ} \mathrm{C}\right)$ & 56.50 & 56.77 & 50.00 \\
\hline $\mathrm{m}_{1}(\mathrm{~kg})$ & 6.0 & 6.0 & 6.0 \\
\hline $\mathrm{m}_{2}(\mathrm{~kg})$ & 4.5 & 4.0 & 3.5 \\
\hline $\mathrm{M}(\mathrm{kg})$ & 1.5 & 2.0 & 2.5 \\
\hline $\mathrm{m}_{\mathrm{a}}(\mathrm{kg})$ & - & - & 3.0 \\
\hline
\end{tabular}




\begin{tabular}{|l|l|l|l|}
\hline $\mathrm{m}_{\mathrm{b}}(\mathrm{kg})$ & - & - & 2.5 \\
\hline $\mathrm{M}_{\mathrm{c}}(\mathrm{kg})$ & - & - & 0.5 \\
\hline R.H $(\%)$ & 16.6 & 13.14 & 11.26 \\
\hline
\end{tabular}

$\mathrm{m}_{1}=$ mass of groundnut before solar drying

$\mathrm{m}_{2}=$ mass of groundnut after solar drying

$\mathrm{M}=$ mass of moisture evaporated from solar dried groundnut

$\mathrm{m}_{\mathrm{a}}=$ mass of groundnut before open-sun drying

$\mathrm{m}_{\mathrm{b}}=$ mass of groundnut after open sun drying

$\mathrm{M}_{\mathrm{c}}=$ mass of moisture evaporated from open - sun dried groundnut

The averages of the data collected from $29^{\text {th }}$ September 2012, to $1^{\text {st }}$ October 2012 are shown in Table 1. the highest ambient temperature of $33.39^{\circ} \mathrm{C}$ was recorded on the first day of the study, which was $29^{\text {th }}$ of September 2012, and the reason was because solar insolation was highest about $808.36 \mathrm{~W} / \mathrm{m}^{2}$ on that day. The solar collector's temperature was also highest about $70.39^{\circ} \mathrm{C}$ on the first day of the test, but the mass of moisture evaporated from the groundnut was least about $1.5 \mathrm{~kg}$ on the first day, the reason was because the relative humidity was highest about $16.6 \%$ on the first day, which means that the atmospheric air was not well dried enough to take away moisture from groundnut, when compared to the relative humidity of the second and the third day, as seen in table one.

On the second day which was $30^{\text {th }}$ of September 2012, the relative humidity was about $13.14 \%$, which was lower than that of the first day, and it was one of the reasons why the mass of moisture evaporated from groundnut during solar drying was about $2.0 \mathrm{~kg}$ which was relatively higher than that of the first day, this was because the atmospheric air was more drier to take away moisture from the groundnut relatively faster than the first day. Still on the second day, the highest temperature of drying chamber about $56.77^{\circ} \mathrm{C}$ and highest dry air temperature about $41.85^{\circ} \mathrm{C}$ were recorded, with least ambient temperature of $32.50^{\circ} \mathrm{C}$ as seen in Table 1.

On the third day, which was $1^{\text {st }}$ of October 2012, the mass of moisture evaporated from the groundnut was highest about $2.5 \mathrm{~kg}$, one of the reasons was because the relative humidity was lowest about $11.26 \%$ as seen in Table 1, it means that the atmospheric air was more drier than the first and second day. Another reason why higher mass of moisture was evaporated from the groundnut on the third day was highest wind speed of about $0.55 \mathrm{~m} / \mathrm{s}$ which translates to higher volumetric and mass flow rates of air, even though the lowest solar insolation of about $587.71 \mathrm{~W} / \mathrm{m}^{2}$, lowest temperature of drying chamber about $50.00^{\circ} \mathrm{C}$, lowest solar collector's temperature of about $61.47^{\circ} \mathrm{C}$ and lowest dry air temperature about $40.44^{\circ} \mathrm{C}$ were recorded.

\section{Statistical Analysis and reliability of test data for efficiency analyses in the study}

The statistical analysis of the data on table 1 was carried out using the following equations;

(i) $\bar{x}=\frac{1}{n} \sum_{i=1}^{n} x_{i}$

Where $x$ is the mean value of test data

$\mathrm{n}$ is the number of observations

$$
\begin{aligned}
& x_{i}=x_{1}+x_{2}+\ldots .+x_{n} \\
& \text { (ii) } \sigma^{2}=\frac{1}{n} \sum_{i=1}^{n}\left(x_{i}-\bar{x}\right)^{2}
\end{aligned}
$$

Where $\sigma^{2}$ is the variance

(iii) $\sigma=\sqrt{\sigma^{2}}$

Where $\sigma$ is the standard deviation

(iv) $S . E .=\frac{\sigma}{\sqrt{n}}$

Where S.E. is the standard error of the mean

(v) The upper and lower limits of Confidence interval (C.I) at $95 \%$ and 0.05 level of significance were calculated using;

$$
\begin{aligned}
& \bar{x} \pm Z_{\alpha}(S . E) \\
& \alpha=0.05
\end{aligned}
$$


This implies that

$\bar{x}+1.96 \times \frac{\sigma}{\sqrt{n}} ; \bar{x}-1.96 \times \frac{\sigma}{\sqrt{n}}$

Where $Z_{0.05}=1.96$

and $\frac{\sigma}{\sqrt{n}}=$ S.E.

The result of the statistical analysis are shown in Table 2, below

Table 2. Result of statistical analysis of test data.

\begin{tabular}{|c|c|c|c|c|c|c|}
\hline & $\bar{x}$ & $\sigma^{2}$ & $\sigma$ & $S . E$. & \multicolumn{2}{|c|}{ Confidence interval } \\
\hline $\mathrm{T}_{\mathrm{a}}\left({ }^{\mathrm{o}} \mathrm{C}\right)$ & 33.01 & 0.211 & 0.459 & 0.265 & $\begin{array}{l}\text { upper limit } \\
35.53\end{array}$ & $\begin{array}{l}\text { lower limit } \\
32.49\end{array}$ \\
\hline $\mathrm{T}_{\mathrm{c}}\left({ }^{\circ} \mathrm{C}\right)$ & 66.38 & 20.508 & 4.529 & 2.165 & 71.51 & 61.25 \\
\hline $\mathrm{T}_{\mathrm{d}}\left({ }^{\circ} \mathrm{C}\right)$ & 54.42 & 14.693 & 3.833 & 2.213 & 58.76 & 50.08 \\
\hline $\mathrm{T}_{\mathrm{h}}\left({ }^{\circ} \mathrm{C}\right)$ & 41.26 & 0.539 & 0.734 & 0.424 & 42.09 & 40.42 \\
\hline $\mathrm{T}_{\mathrm{w}}\left({ }^{\circ} \mathrm{C}\right)$ & 28.00 & 5.509 & 2.347 & 1.355 & 30.66 & 25.34 \\
\hline $\mathrm{I}_{\mathrm{c}}\left(\mathrm{W} / \mathrm{m}^{2}\right)$ & 722.8 & 14012.5 & 118.3 & 68.344 & 856.76 & 587.61 \\
\hline $\mathrm{v}(\mathrm{m} / \mathrm{s})$ & 0.52 & $\begin{array}{l}0.00053 \\
3\end{array}$ & 0.0231 & 0.013 & 0.55 & 0.49 \\
\hline $\mathrm{RH}(\%)$ & 13.67 & 7.337 & 2.709 & 1.564 & 16.74 & 10.61 \\
\hline
\end{tabular}

As seen in table 2, the range of the test data in Table 1 falls within the upper and lower limits of $95 \%$ confidence interval and 0.05 level of significance as shown in table 2, which implies that the test data should be accepted because it is reliable.

Volumetric flow rate of air in the study

The volumetric flow rate of air was calculated using equation (2) below

$V_{a}=\pi r^{2} \times v \times n=\pi v r^{2} n$

$\mathrm{V}_{\mathrm{a}}=3.142 \times(0.05)^{2} \times 0.52 \times 4=0.0163384 \mathrm{~m}^{3} / \mathrm{s}$

The solar collector's efficiency $\left(n_{c}\right)$ in the study

The solar collector's efficiency was calculated using equation (20) as follows

$\eta c=\frac{\rho V_{a} C_{p} \Delta T}{I_{c} A_{c}}=\frac{1.225 \times 0.0163384 \times 1.000 \times 34.73}{0.722 \times 3.390}=\frac{0.695}{2.448}=0.283 \times 100=28.3 \%$

$\left[\Delta \mathrm{T}=\mathrm{T}_{\mathrm{c}}-\mathrm{T}_{\mathrm{a}}=(339.8-306.1) \mathrm{K}=34.73 \mathrm{~K}\right]$

From table 4.1

$\mathrm{M}=\frac{1.5+2.0+2.5}{3}=\frac{6.0}{3}=2.0 \mathrm{~kg}$

The solar dryer's efficiency $\left(n_{d}\right)$ in the study

The solar dryer's efficiency was calculated using equation (19) as follows

$\eta_{d}=\frac{M L}{I_{c} A_{c} t}=\frac{2.0 \times 2.260}{0.722 \times 3.390 \times 8.00}=\frac{4.52}{19.581}=0.230 \times 100=23.0 \%$

\section{Comparism of efficiencies in the study}


As it is clearly seen, the solar collector's efficiency obtained in the study was $28.3 \%$, which is greater than $10 \%$ obtained by Ezekoye and Enebe, (2006). Also looking at the solar dryer's efficiency obtained in the study was $23.0 \%$ which is greater than $11 \%$ obtained by Senger, (2009) and 22\% obtained by Ezekoye and Enebe, (2006). The solar collector's efficiency was greater than the dryer's efficiency, as it has always been in most cases. Dividing the dryer's efficiency with collector's efficiency, we obtain the system efficiency $\left(\eta_{s}\right)$ (Aklilu,2004). The system efficiency in the study was $81.3 \%$

\section{Drying rate of groundnut in the study.}

From Table 1, we can conclude that $2.0 \mathrm{~kg}$ of moisture was evaporated from $6.0 \mathrm{~kg}$ of fresh groundnut in a drying period of 8 hours during solar drying. This implies that considering the mass of moisture evaporated and time of evaporation, the drying rate of fresh groundnut under solar drying was $0.25 \mathrm{~kg} / \mathrm{hr}$, which means that $0.25 \mathrm{~kg}$ of moisture is evaporated from the fresh groundnut in one hour. Also for the one day open sun drying, $0.5 \mathrm{~kg}$ of moisture was evaporated from $3.0 \mathrm{~kg}$ of fresh groundnut which means that drying rate of fresh groundnut under open sun drying was $0.0625 \mathrm{~kg} / \mathrm{hr}$. Solar drying was four times faster that open sun drying.

\section{Effect of temperatures and solar insolation on drying rate in the study}

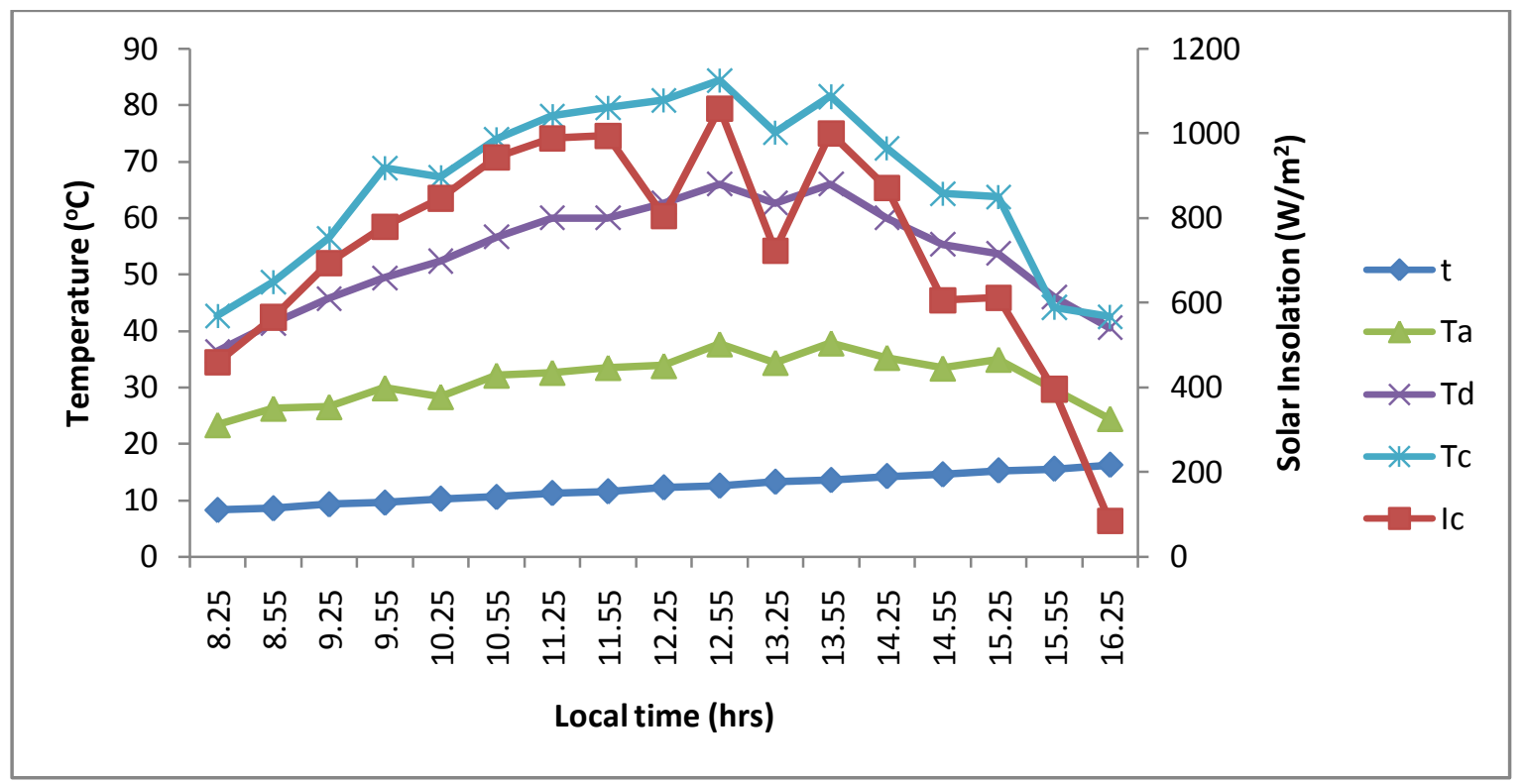

Figure 1. The graph of solar insolation $\left(\mathrm{I}_{c}\right)$, ambient temperature $\left(\mathrm{T}_{\mathrm{a}}\right)$, solar collector's temperature $\left(\mathrm{T}_{\mathrm{c}}\right)$ and temperature of drying chamber $\left(\mathrm{T}_{\mathrm{d}}\right)$ with local time $(\mathrm{t})$

From figure 1 above, the temperature of the drying chamber rose from above $30^{\circ} \mathrm{C}$ in the morning hours and reached above $50^{\circ} \mathrm{C}$ from $10.55 \mathrm{hrs}$ to $15.25 \mathrm{hrs}$, and was maintain for over four hours till $15.25 \mathrm{hrs}$. This implies that is capable of retaining moderate heat in the drying chamber for reasonable period of time which enhanced it ability to remove moisture from the groundnut and dry the fresh groundnut relatively faster. Also in figure 1, looking at the ambient temperature curve and solar collector's temperature curve, we could observe that there is a reasonable difference between the two temperatures. For example, the maximum ambient temperature was above $35^{\circ} \mathrm{C}$ at $12.55 \mathrm{hrs}$ and $13.55 \mathrm{hrs}$ while the maximum solar collector's temperature was $80^{\circ} \mathrm{C}$ at $12.55 \mathrm{hrs}$ and $13.55 \mathrm{hrs}$. This temperature difference of about $45^{\circ} \mathrm{C}$, that gives the temperature elevation in the dryer, is significant enough to make the dryer generate enough heat that will easily remove substantial part of moisture in the fresh groundnut thereby drying it faster. Likewise, in the same figure, solar insolation above $600 \mathrm{~W} / \mathrm{m}^{2}$ was maintained in most hours of the days, especially from $9.25 \mathrm{hrs}$ to $13.55 \mathrm{hrs}$. The highest was above $1000 \mathrm{~W} / \mathrm{m}^{2}$ with the least less than $100 \mathrm{~W} / \mathrm{m}^{2}$ at $16.24 \mathrm{hrs}$, the lowest solar insolation at $16.25 \mathrm{hrs}$ was due to cloud cover. Generally the solar insolation in most hours of the day was adequate to generate reasonable ambient temperature, solar collector's temperature and drying chamber's temperature which consequently facilitated and fasten the rate at which moisture was removed from the groundnut

Variation solar collector's efficiency and solar insolation with time 


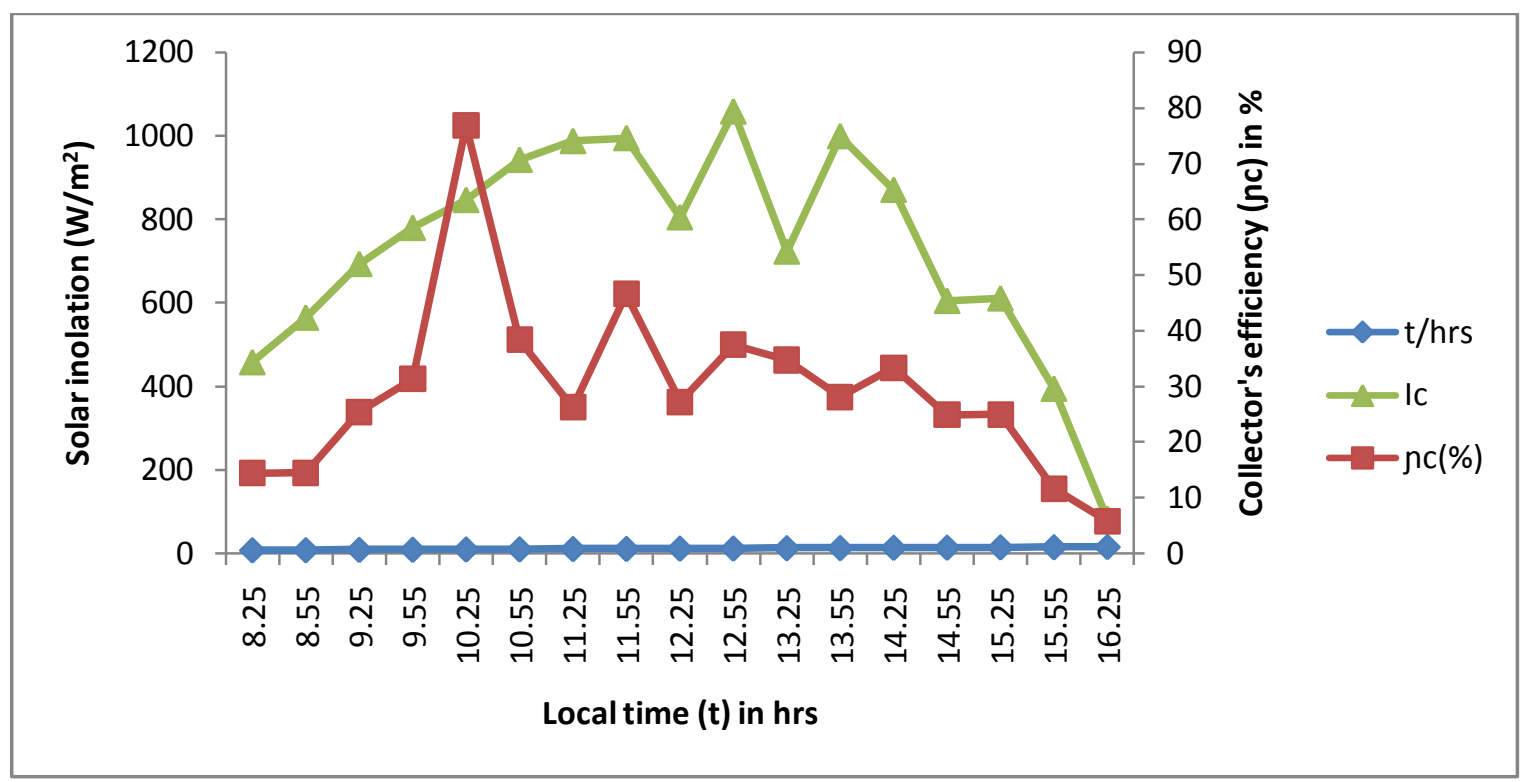

Figure 2. The graph of solar insolation $\left(I_{c}\right)$ and solar collector's efficiency (nc) with time (t)

As seen in figure 2, the solar collector's efficiency was less than 30\% for about five out of eight hours of the days during the test which confirms the average solar collector's efficiency of $28.3 \%$ calculated, Also as shown in fig. 2, solar collector's efficiency was slightly above $30 \%$ for about two hours of the days of the study and was between $40 \%$ to slightly above $70 \%$ in only one hour of the days.

While the solar collector's efficiency was slightly above $70 \%$ at 10.25 hours, the solar insolation reached the highest value, slightly above $1000 \mathrm{~W} / \mathrm{m}^{2}$ at $12.55 \mathrm{hrs}$, but solar insolation above $600 \mathrm{~W} / \mathrm{m}^{2}$ was maintained in most hours of the days during the test, especially from $9.25 \mathrm{hrs}$ to $13.55 \mathrm{hrs}$.

\section{Effect of relative humidity and solar insolation on drying rate in the study}

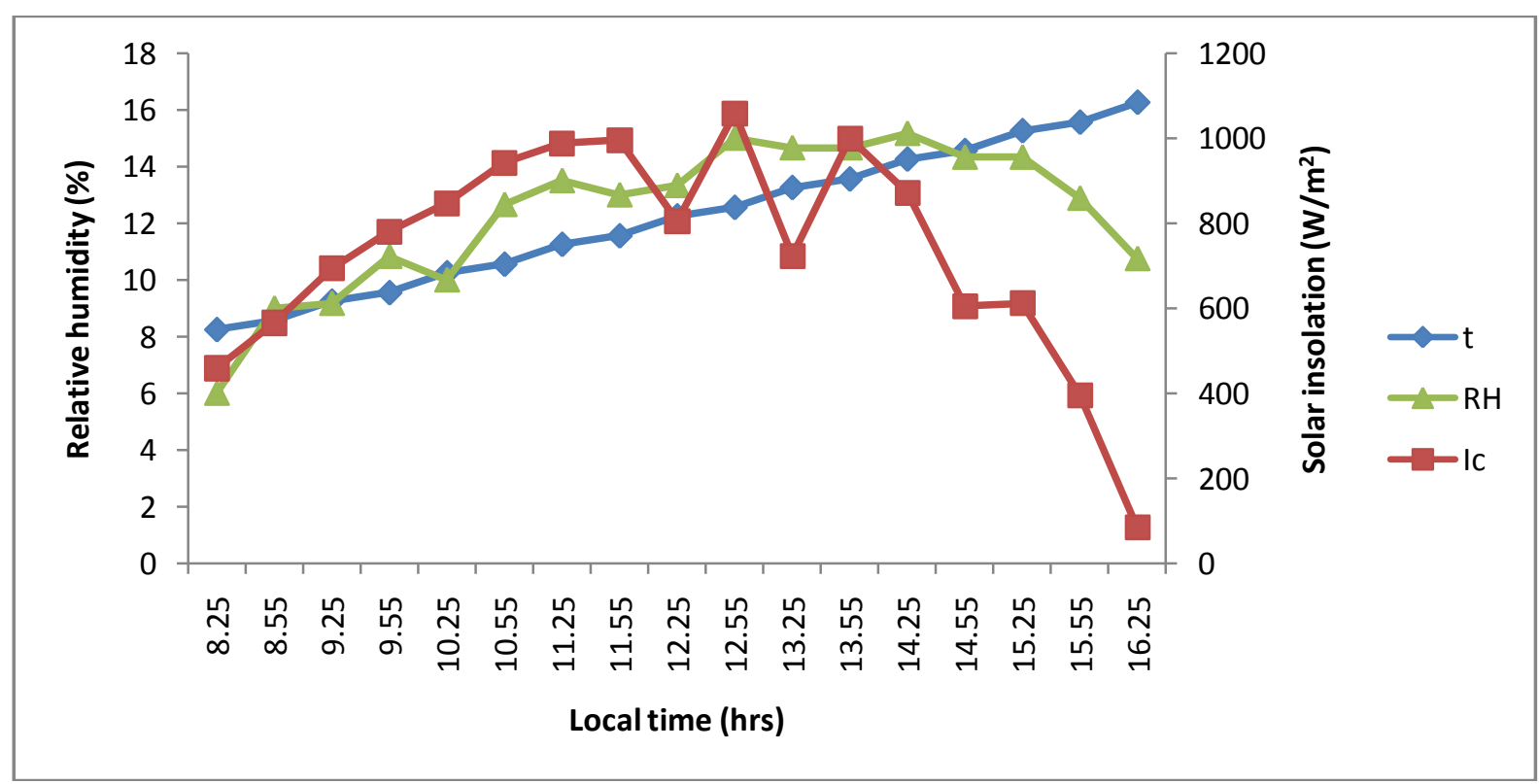

Figure 3. The graph of relative humidity (RH) and solar insolation (Ic) with local time (t)

From figure 3, the relative humidity was generally low with the least about $6 \%$ in the morning hours at $8.25 \mathrm{hrs}$ and the highest less than $16 \%$ around the mid- day. Lower relative humidity of less than $16 \%$ with a moderate solar insolation of slightly above $600 \mathrm{~W} / \mathrm{m}^{2}$ implies that the air circulating in the drying chamber was fairly hot and dry to take away reasonable amount of moisture from the fresh groundnut to the atmosphere which will lead to faster drying rate of the groundnut. 


\section{Effect of volumetric flow rate and wind speed on drying rate of groundnut in the study}

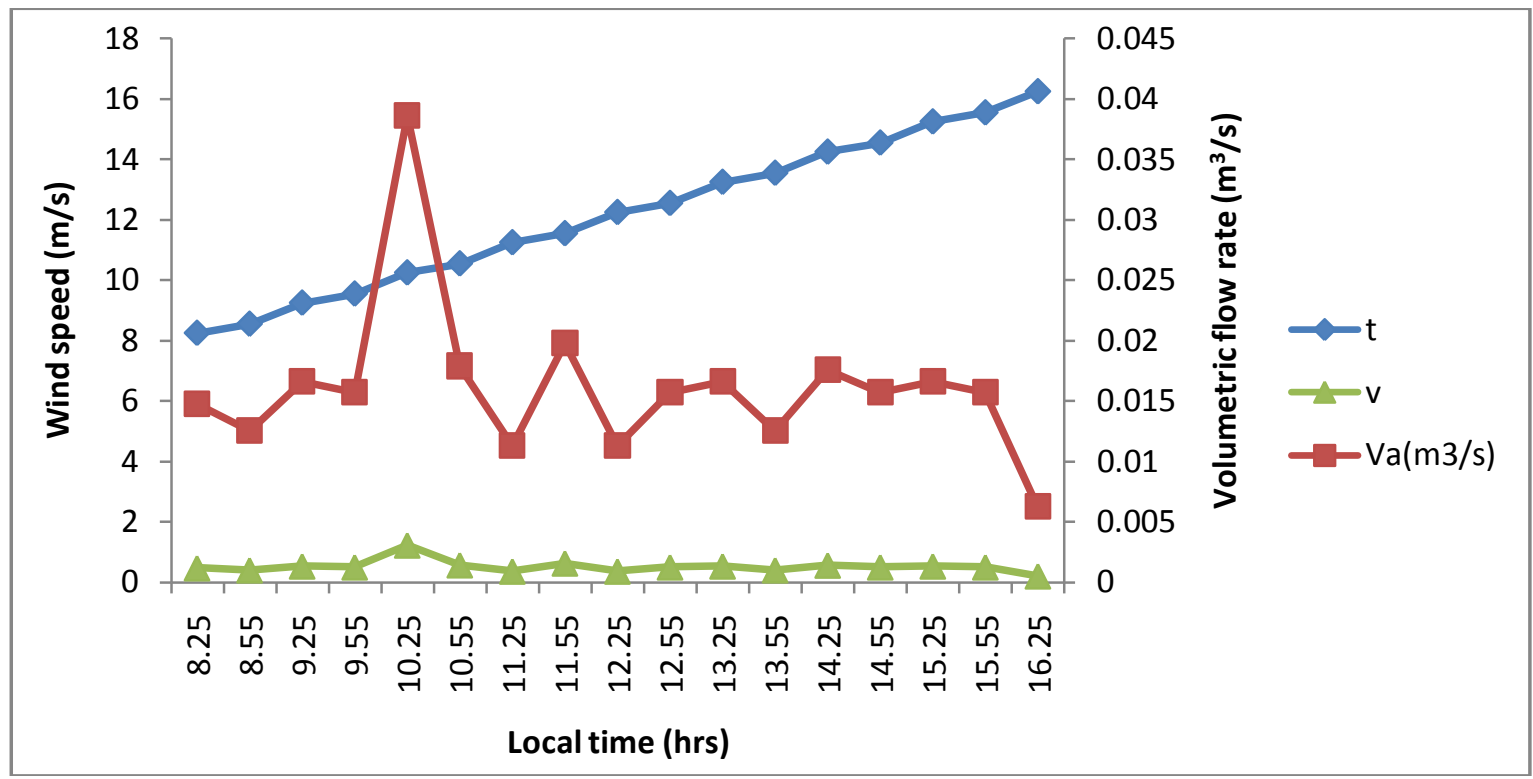

Figure 4. The graph of wind speed $(v)$ and volumetric flow rate $\left(\mathrm{V}_{\mathrm{a}}\right)$ against local time $(\mathrm{t})$

As seen in figure 4 , the highest wind speed recorded was slightly above $1.0 \mathrm{~m} / \mathrm{s}$ at $10.25 \mathrm{hrs}$, which also lead to the highest volumetric flow rate of air almost $0.04 \mathrm{~m}^{3} / \mathrm{s}$ at the same time in the study. But in most hours of the days in the study, the volumetric flow rate of air was between $0.015 \mathrm{~m}^{3} / \mathrm{s}$ and $0.020 \mathrm{~m}^{3} / \mathrm{s}$, while the wind speed was below $1.0 \mathrm{~m} / \mathrm{s}$ in most hours of the days of the study. This clearly shows that there is a direct proportion between wind speed and volumetric flow rate of air in the natural convection solar dryer designed and constructed in the study

\section{Conclusion}

The performance evaluation of an adjustable and collapsible box type natural convection solar food dryer was successfully carried out. The dryer has a solar collector's efficiency of $28.3 \%$, dryer's efficiency of $23.0 \%$ and system efficiency of $81.3 \%$, with a drying rate of $0.25 \mathrm{~kg} / \mathrm{hr}$, which was four times greater than the drying rate of open sun that was $0.0625 \mathrm{~kg} / \mathrm{h}$ in the study.

\section{Refrences}

[1]. Aklilu, T. (2004): "Experimental Analysis for Performance Evaluation of Solar Food dryer". Research Thesis. Department of Mechanical Engineering. School of Graduate Studies, Addis Ababa University.

[2]. Bukola, O. B ; Ayoola, P. O. (2008): Performance Evaluation of a Mixed- Mode Solar Dryer. A.U.J.T. 11(4): 225- 231

[3]. Bolaji, B. O (2005): Development and Performance Evaluation of a Box Type Absorber Solar Air Collector for Crop Drying. Journal of food technology 3 (4): $595-600$.

[4]. Bassy, M.W (1989) :Development and Use of Solar Drying Technologies. Nigerian Journal of Solar Energy. 89:133- 64

[5]. Ceankoplis, C. J (1993) : Transport Process and Unit Operations. $3^{\text {rd }}$ Edition Prentice Hall, Englewood: 508-512

[6]. Diamante, L.M ; Munro, P.A, (2004), Mathematical Modelling of Thin Layer Solar Drying of Sweet Potatos, Solar Energy,(51) $176-271$

[7]. Ezekoye, B.A ; Enebe, O.M (2006): "Development and Performance Evaluation of Modified Integrated Passive Solar Grain Dryer". Pacific Journal of Science and Technology. 7(2) : 185- 190.

[8]. Geda- Gujurat Energy Development Agency, 2003, www.geda.com

[9]. Hallak, H; Hilal. J; Rahhal, .R (1996): The Staircase Solar Dryer and Characteristics. Renewable Energy. 7 (2) : $177-183$.

[10]. Harringshaw, D. (1997): All About Food Drying, The Ohio State University Extension Facts Sheet - hyg - 5347- 97, www.ag.ohio-state.edu/

[11]. Mahmoud, M.G. (2009): Thermal Energy Materials and System Optimization for Solar $\quad$ Drying and Cooking Applications. P.hD Thesis. Department of Built Environment, Faculty of Engineering, University of Nottingham, United kingdom. 2009

[12]. Nejat, T. V, (1989): Alternative Energy Sources viii, Hemisphere Publishing Company, 1

[13]. Nandi, P (2009): Solar Thermal Energy Utilization in Food Processing Industry in India, Percific Journal of Science and Technology 10 (1) :123- 131

[14]. Olaloye, D. O (2008) : The Design and Construction of Solar Incubator, 2008 Project Report, Submitted to Department of Mechanical Engineering, University of Agriculture, Aboekuta.

[15]. Oguntola, J. A ; Collins, N. N ; Olayinka, A. (2010): "Design and Construction of a Domestic Passive Solar Food Dryer". Leonardo Journal of Sciences. 16

[16]. Roger, G ; Gregoire, P. E (2010) : Understanding Solar Food Dryers. VITA Technical Paper. 15 (11) 1-27

[17]. Senger, S.H; Khandetod Y.P; Mohod, A.G (2009) : "Low Cost Solar Dryer for Fish". African Journal of Environmental Science and Technology. 3(9) 265-271. 
[18]. Sukhatme, S. P. (1996) : Solar Energy Principles of Thermal Collection and storage, Tata McGraw Hill Publishing Company Limited, 1996.

[19]. Scalin, D. (1997): The Design, Construction and Use of an Indirect Through Pass Solar Food 'Dryer. Home Power Magazine. 57 : $62-72$.

[20]. Togrul, I.T; Pehlivan, D. (2004): Modelling of Thin Layer Drying Kinetics of some Fruits Under $\quad$ Open Air Sun Drying Process, J.Food Engin. 65:413-25

[21]. Whitefield, D.E. (2000) Solar Dryer Systems and Internet, Important Resources to Improve Food Preparation. 2000 Proceedings of International Conference on Solar Cooking, Kimberly, South Africa.

[22]. Yousef- Ali, S; Messaoudi, H ; Desmons, J. Y ; Abene, A ; Le Ray, M (2001) : Detrmination of the Average Co - efficient of Internal Moisture Transfer During the Drying of a Thin Bed Potato Slices. J. Food Engin. 48 (2): 95 - 101. 